İsletme Bilimi Dergisi 2020

Cilt:8 Sayı:2
SAKARYA ÜNIVERSITESI
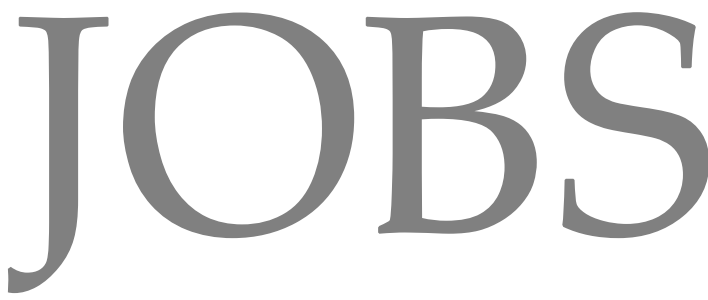

İşletme Bilimi Dergisi

The Journal of Business Science

Sakarya Üniversitesi / Sakarya University İşletme Fakültesi / Sakarya Business School

$\begin{array}{ll}\text { Cilt/Volume } & : 8 \\ \text { Say1/Issue } & : 2 \\ \text { Yil/Year } & : 2020\end{array}$

ISSN: 2148-0737

DOI: $10.22139 /$ jobs 
İşletme Bilimi Dergisi 2020 Cilt:8 Sayı:2

ii

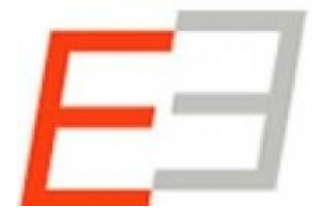

Akademilk Ansustumalari Indeksi
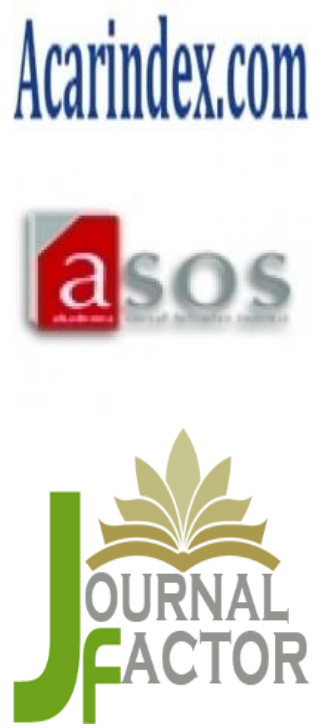
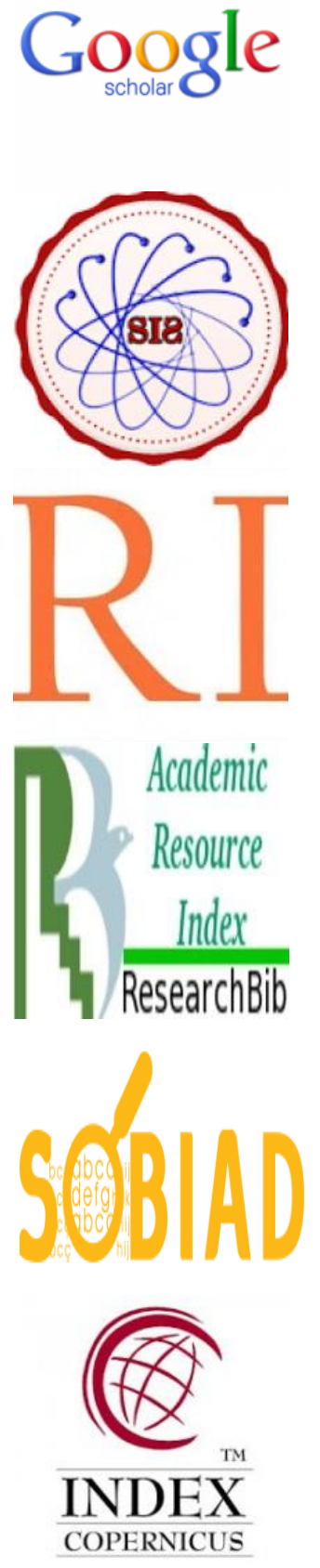
Kurucu Sahip/Founder

Prof. Dr. Gültekin YILDIZ

Imtiyaz Sahibi / Owner

Prof. Dr. Kadir ARDIÇ

Editör / Editor

Prof. Dr. Mahmut AKBOLAT

Editör Yardımcılarn / Assoc. Editors

Prof. Dr. Mustafa Cahit UNGAN

Mizanpaj Editörü / Layout Editor

Arş. Gör. Mustafa AMARAT
Işletme Bilimi Dergisi

2020

Cilt:8 Sayı:2

\section{Danışma Kurulu/Advisory Board}

Prof. Dr. Ahmet Vecdi CAN

Prof. Dr. Bülent SEZEN

Prof. Dr. Dilaver TENGİLIMOĞLU

Prof. Dr. Erman COŞKUN

Prof. Dr. Kadir ARDIÇ

Prof. Dr. Mehmet BARCA

Prof. Dr. Nihat ERDOĞMUŞ

Prof. Dr. Orhan BATMAN

Prof. Dr. Recai COŞKUN

Prof. Dr. Remzi ALTUNIŞIK

Prof. Dr. Selahattin KARABINAR

Prof. Dr. Sidika KAYA

Prof. Dr. Şevki ÖZGENER

Prof. Dr. Türker BAŞ

Doç. Dr. Surendranath Rakesh JORY
Sakarya Üniversitesi

Gebze Yüksek Teknoloji Enstitüsü

Atılım Üniversitesi

İzmir Bakırçay Üniversitesi

Sakarya Üniversitesi

Ankara Sosyal Bilimler Üniversitesi

İstanbul Şehir Üniversitesi

Sakarya Üniversitesi

İzmir Bakırçay Üniversitesi

Sakarya Üniversitesi

İstanbul Üniversitesi

Hacettepe Üniversitesi

Nevşehir Üniversitesi

Galatasaray Üniversitesi

Southampton Üniversitesi 
İşletme Bilimi Dergisi

2020

Cilt:8 Sayı:2

It is assumed that the articles submitted for publication in our journal are written in ethical principles and the authors have obtained the necessary legal approvals from the relevant ethics committee. The responsibility of this matter belongs to the authors. Scientific responsibility for the articles belongs to the authors themselves. Published articles could be cited in other publications provided that fullreferenceisgiven.

İşletme Bilimi Dergisi; www.dergipark.gov.tr/jobs SakaryaÜniversitesi İşletme Fakültesi jobs@sakarya.edu.tr Esentepe Kampüsü 54187 Serdivan/SAKARYA 
Bu Sayıda Katkıda Bulunan Hakemler Reviewers List of This Issue

Prof. Dr. Üyesi Muharrem Es Doç. Dr. Emrah Özsoy

Doç. Dr. Hakan Murat Arslan Doç.Dr. Oğuz Işık

Dr. Öğr. Üyesi Beyza Erkoç

Dr. Öğr. Üyesi Gökhan Aba

Dr. Öğr. Üyesi Gülcan Şantaş

Dr. Öğr. Üyesi İsa Gül

Dr. Öğr. Üyesi Meltem Saygılı

Dr. Öğr. Üyesi Metin Bayram

Dr. Öğr. Üyesi Osman Kürşat ACAR

Yalova Üniversitesi

Sakarya Üniversitesi

Düzce Üniversitesi

Hacettepe Üniversitesi

Sakarya Üniversitesi

Kırıkkale Üniversitesi

Sakarya Üniversitesi

Sülayman Demirel Üniversitesi
İşletme Bilimi Dergisi 2020

Cilt:8 Sayı:2

Zonguldak Bülent Ecevit Üniversitesi

Bandırma Onyedi Eylül Üniversitesi

Afyonkarahisar Sağlık Bilimleri Üniversitesi 
Değerli Bilim Insanları,

İşletme Bilimi Dergisinin 8. Cilt 2. Sayısını yayınlamaktan dolayı mutluluk duyuyoruz. Dergimiz kurulduğu günden bugüne kadar olduğu gibi farklı disiplinlerden gelen makaleler ile sizlere zengin bir içerik sunmaktadır. 8. Cilt 2. Sayımız toplam 6 makale ile yayınlanmıştır.

Sayımızın ilk makalesi Gülseren Çelebi Gürsoy ve Mehmet Selami Yıldız tarafindan kaleme alınan "Bir imalat işletmesinde analitik hiyerarşi prosesi tabanl yalın üretim tekniği seçimi" başlıkl makaledir. Bu makalede yazarlar bir imalat işletmesinde uygulanan yalın üretim uygulamalarının tercih edilme eğilimlerini Analitik Hiyerarşi Prosesi (AHP) yöntemi ile belirlemek ve bu bağlamda da işletme de uygulanan hangi yalın üretim tekniğinin daha önemli olduğunu tespit etmeyi amaçlamışlardır.

Arif Yuldiz ve Tuncay Yilmaz'ın eseri olan "Uluslararası mesleki uygulama çerçevesi açısından iç denetim süreci ve değerlendirilmesi" makale uluslararası iç denetim standartlart ve rehberler temelinde iç denetimin değerlendirilmesi, temel süreçlerinin çizilmesi ve iç denetimin daha kolay anlaşılır ve uygulanır hale getirilmesini amaçlamaktadır.

Sayımızın 3. makalesi mikrobiyoloji laboratuvarına tıbbi bölümlerden gelen tetkik istemlerinin gereksizlik, maliyet ve süre açısından retrospektif yaklaşımla analizini amaçlamaktadır. Bu makale Yunus Fidan, Yunus Emre Öztürk, Uğur Ayan ve Mehmet Özdemir tarafindan kaleme alınan makale "Akılcı laboratuvar kullanımı açısından gereksiz tetkik istemlerinin retrospektif analizi: seroloji laboratuvarı örneğgi" başlığını taşımaktadır.

Sayımızda yer alan bir diğger makale Aysun Yeşiltaş ve Ahmet Yeşiltaş tarafindan yazllan "geleneksel ve Tamamlayıc Tip hizmeti veren kurumlarm web sitelerinin değerlendirilmesine yönelik bir içerik analizi" başlıklı makaledir. Bu makalede yazarlar kurumlarda sunulan geleneksel ve tamamlayıci tip uygulamalarının ne ölçüde kurum web sitelerinde yayınlandığ 1 ve bu hizmetlere ilişkin bilgilerin kurum web sitelerinde yayınlanma durumlarının belirlenmesini amaçlamışlardır.

Dergimizin bu sayısında yer alan "Algılanan örgütsel desteğin örgüt sağhlğgl üzerindeki etkisi: hastane çalışanlarına yönelik bir araştırma" başlıkl makalesi İsa Gül, Nezihe Tüfekci ve Derya Sarıoğlu tarafindan kaleme alınmıştır. Bu makalenin amacı hastane çalışanlarının işgören algıladıkları örgütsel desteğin örgüt sağllk üzerindeki etkisini incelemektir.

Sayımızın son makalesi ise hastane çalışanlarının psikolojik sağlamlıkları ile iş stresi düzeyleri arasindaki ilişkiyi belirlemek amacıyla Serkan Deniz, Mesut Çimen ve Onur Yüksel tarafından kaleme alınan "Psikolojik să̆lamlı̆̆ın iş stresine
İşletme Bilimi Dergisi

2020

Cilt:8 Sayı:2 
İsletme Bilimi Dergisi

2020

Cilt:8 Sayı:2 etkisi: hastane çalışanlarına yönelik bir araştırma" başlıklı makaledir.

Önceki sayılarımızda olduğu gibi bu sayımızda da İşletme Biliminin farklı disiplinlerinden makaleler ile okuyumucuzun karşınıa çıkmaktan onur duymaktayız. Dergi politikası olarak bundan sonraki sayılarımızda da işletme bilimine dayalı farklı disiplinlerden gelen çalışmaları yayınlamaya özen göstereceğiz. Sayımıza makaleleri ile katkı să̆layan yazarlarımıza şükranlarımızı sunarken, bu makaleleri değerlendirmek için kıymetli vakitlerinden fedakarlik yapan hakemlerimize ve bu sayımızda emeği geçen tüm dergimiz çalışanlarına sonsuz teşekkürü borç bilirim. Dergimizin okurlarımız ve bilim insanlarına faydalı olması dileklerimle sonraki sayılarımızda işletmeciliğin güncel çalışmaların bilim dünyasının hizmetine sunmak için siz değerli bilim insanları ve araştırmacıların katkılarm bekliyoruz.

$$
\text { Saygilarımizla... }
$$

Prof. Dr. Mahmut AKBOLAT

Editör 


\section{İĊiNDEKİLER/CONTENTS}

\author{
Yal (Year) 2020 Cilt (Vol.) 8 Sayl (No) 2
}

\section{Araştırma Makaleleri/Research Articles}

Bir İmalat İşletmesinde Analitik Hiyerarşi Prosesi Tabanlı Yalın Üretim Tekniği Seçimi

Selection Of Analytical Hierarchy Process Based Lean Productıon Technique In A Manufacturnng

Business

Gülseren ÇELEBİ GÜRSOY ve Prof. Dr. Mehmet Selami YILDIZ

Uluslararası Mesleki Uygulama Çerçevesi Açısından İç Denetim Süreci Ve

Değerlendirilmesi

Internal Audit Process And Evaluation In Terms Of International Professional Practices

Framework

Arif YILDIZ ve Prof. Dr. Tuncay YILMAZ

Akılcı Laboratuvar Kullanımı Açısından Gereksiz Tetkik İstemlerinin Retrospektif

Analizi: Seroloji Laboratuvarı Örneği

Retrospective Analysis Of Unnecessary Test Prompts In Terms Of Rational Use Of Laboratory:

Serology Laboratory Case

Yunus FIDAN, Doç. Dr. Yunus Emre ÖZTÜRK, Uzm. Dr. Uğur AYAN ve Prof. Dr. Mehmet ÖZDEMIR

Geleneksel Ve Tamamlayıcı Tıp Hizmeti Veren Kurumların Web Sitelerinin

Değerlendirilmesine Yönelik Bir İçerik Analizi

A Content Analysis For The Evaluation Of Web Sites Of Traditional And Complementary Medicine Services

307-324

Dr. Özlem DEMIR ve Prof. Dr. Zekai ÖZTÜRK

Algılanan Örgütsel Desteğin Örgüt Sağlığı Üzerindeki Etkisi: Hastane Çalışanlarına

Yönelik Bir Araştırma

The Effect Of Perceived Organizational Support On Organizational Health: A Research On Hospital 325-350 Employees

Dr. Öğr. Üyesi İsa GÜL, Doç. Dr. Nezihe TÜFEKCİ ve Derya SARIOĞLU

Psikolojik Sağlamlığın İş Stresine Etkisi: Hastane Çalışanlarına Yönelik Bir Araştırma The Effect Of Resilience On The Job Stress: A Study On Hospital Employees
Işletme Bilimi Dergisi

2020

Cilt:8 Sayı:2

Dr. Öğr. Üyesi Serkan Deniz, Prof. Dr. Mesut Çimen ve Öğr. Gör. Onur Yüksel 


\title{
PSİKOLOJİK SAĞLAMLIĞIN İŞ STRESİNE ETKİSİ: HASTANE ÇALIŞANLARINA YÖNELIKK BİR ARAŞTIRMA
}

\author{
Dr. Öğr. Üyesi Serkan Deniz \\ Yalova Üniversitesi Termal Meslek Yüksekokulu \\ serkand100@gmail.com \\ ORCID ID: orcid.org/ 0000-0002-8093-1336 \\ Prof. Dr. Mesut Çimen \\ Acıbadem Mehmet Ali Aydınlar Üniversitesi Sağlık Bilimleri Fakültesi \\ mesut.cimen@acibadem.edu.tr \\ ORCID ID: orcid.org/ 0000-0002-0937-9411 \\ Öğr. Gör. Onur Yüksel \\ Yalova Üniversitesi Termal Meslek Yüksekokulu \\ onuryuksel41@gmail.com \\ ORCID ID: orcid.org/ 0000-0002-0055-1326
}

Psikolojik Sağlamlığın İş Stresine Etkisi:

Hastane

Çalışanlarına

Yönelik Bir

Araştırma

\begin{abstract}
ÖZ
Amaç: Bireyler yaşamları boyunca birçok olumsuzlukla karşı karşıya kalabilmektedirler. Bireylerin psikolojik sağlamlık düzeylerinin yüksek olması bu olumsuzluklarla daha kolay mücadele edebilmesini sağlamaktadır. Bireylerin psikolojik sağlamlık düzeylerinin yüksek olması çalışma hayatı için de önemli bir avantajdır ve çalışanlara birçok konuda fayda sağlamaktadır. Psikolojik sağlamlığın sağladığı faydalardan biri de çalışanların iş stresini azaltmasıdır. Bu çalışma ile hastane çalışanlarının psikolojik sağlamlıkları ve iş stresi düzeylerinin demografik özelliklere göre farklılık gösterip göstermediğinin; ayrıca psikolojik sağlamlık ile iş stresi düzeyleri arasındaki ilişkinin belirlenmesi amaçlanmıştır.
\end{abstract}

Yöntem: Araştırma Ocak 2020 - Mayıs 2020 aylarında İstanbul'da gerçekleştirilmiştir. Araştırma verileri İstanbul'da faaliyet gösteren özel hastanelerde çalışan bireylerden toplanmıştır. Araştırma verileri anket yöntemi ile toplanmıştır. Araştırma kapsamında 391 anket formu toplanmıştır.

Bulgular: Araştırma ile katılımcıların psikolojik sağlamlık ve iş stresi düzeylerinin orta düzeyde olduğu belirlenmiştir. Katılımcıların yaşına, eğitim durumuna ve hastanedeki çalışma süresine göre psikolojik sağlamlık ve iş stresi düzeylerinin istatistiksel olarak farklılık göstermediği belirlenmiştir. Ancak katılımcıların cinsiyetine ve hastanedeki görevine psikolojik sağlamlık ve iş stresi düzeylerinin istatistiksel olarak farklılık gösterdiği belirlenmiştir. Araştırma sonuçlarına göre 
Psikolojik

Sağlamlığın İş

Stresine Etkisi:

Hastane

Çalışanlarına

Yönelik Bir

Araştırma

352

psikolojik sağlamlık ile iş stresi arasında istatistiksel olarak anlamlı, negatif yönlü ve orta düzeyde bir ilişkinin olduğu belirlenmiştir. Ayrıca psikolojik sağlamlığın iş stresini negatif yönde etkilediği belirlenmiştir.

Sonuç: Bu araştırmanın sonuçları psikolojik sağlamlığın iş stresinin bir belirleyicisi olduğunu göstermektedir. Araştırma sonuçları çerçevesinde çalışanların psikolojik sağlamlıklarının arttırılması ve iş streslerinin azaltılması için hastane yönetimlerinin bazı çalışmalar yapması önerilmektedir.

Anahtar Kelimeler: Psikolojik Sağlamlık, İş Stresi, Hastane

\title{
THE EFFECT OF RESILIENCE ON THE JOB STRESS: A STUDY ON HOSPITAL EMPLOYEES
}

\begin{abstract}
Aim: Individuals might encounter various negative situations throughout their lives. As the resilience of individuals increases, they are more likely to deal with these problems easily. The higher resilience is an important advantage for individuals in their working life and provides various benefits to employees in many ways. One of the benefits of resilience is that it decreases the job stress of employees. In this study it is aimed to determine whether the resilience and job stress levels of hospital employees differ in line with the demographic characteristics, and to determine the relationship between resilience and job stress levels.
\end{abstract}

Method: This research was performed in Istanbul between January 2020 and May 2020. The data of this research was collected from individuals who work in private hospitals in Istanbul through the survey method. 391 survey forms were filled within the scope of research.

Findings: In the research, it is determined that the resilience and job stress levels of the participants were at a moderate level. It was found that the resilience and job stress levels of the participants do not differ statistically in terms of their age, education level, and working time in the current hospital. However, it was found that the resilience and job stress levels of the participants differ statistically in terms of their gender and the task of the hospital. Depending on the research results, a statistically significant, negative, and moderate relationship was found between resilience and job stress. Furthermore, it was found that resilience affects job stress negatively.

Results: The results of this research shows that resilience is a determinant of job stress. Under the light of these research results, it is suggested that the hospital administrations should give some efforts to increase the resilience of the employees and to reduce job stress.

Keywords: Resilience, Job Stress, Hospital 


\section{GİRIŞ}

Bireyler yaşamları boyunca birçok olumsuzlukla ve sarsıcı yaşam olaylarıyla karşı karşıya kalabilmektedirler. Bu olumsuzluklara karşı bireylerin verdikleri tepkiler farklılık gösterebilmektedir. Bazı bireyler olumsuzluklar karşısında istenmeyen tutum ve davranışlar sergilerken veya anksiyete, depresyon gibi çeşitli sorunlar yaşarken, bazı bireyler ise yaşanan olumsuzlukların etkisinden çok kısa sürede kurtulabilmekte ve hızlı bir şekilde günlük yaşamlarına dönebilmektedirler. Bireylerin olumsuzluklar karşısında kendilerini toparlayabilme ve hızlı bir şekilde günlük yaşantılarına dönebilme güçleri pozitif psikoloji yaklaşımında, psikolojik sağlamlık kavramıyla açıklanmıştır (Doğan, 2015:93). Psikolojik sağlamlık günlük yaşamda olduğu gibi çalışma hayatı için de önemli bir kavramdır. Psikolojik sağlamlık, çalışanların işyerinde karşılaştıkları olumsuzluklarla başa çıkabilmelerini sağlayan olumlu duygulardan biridir (Cooke et al., 2019:695).

Bireyler zamanlarının önemli bir kısmını işyerlerinde ya da işleriyle ilgili faaliyetlerle uğraşarak geçirmektedirler. Bu süre zarfında çalışanlar birçok stres faktörü ile karşı karşıya kalabilmekte ve dolayısıyla çalışanların işe bağlı stres yaşamaları kaçınılmaz hale gelmektedir (Çınar, 2010:117). Küreselleşmenin etkisiyle beraber günümüz çalışma hayatında büyük değişimler yaşanmıştır. Yaşanan bu değişimler çalışanlar üzerindeki baskıyı ve çalışanlar arası rekabeti artırmış, çalışanların yeniliklere ve değişimlere uyum sağlamak için sürekli çabaladığı ve zorlandığı görülmüştür. Bu nedenlerle beraber yaşanan ekonomik krizler, işsizlik, iş hayatındaki belirsizlikler, çevresel problemler, artan kentleşme, ulaşım ve iletişim problemleri gibi sorunlar günümüz çalışanlarının işe bağlı stresini daha da yoğun bir şekilde hissetmesine neden olmuştur (Örücü vd., 2011:2; Çögenli ve Erdal, 2018:498; Türk vd., 2008:3). Çalışanların işe bağlı olarak yaşadığ 1 stres onların çalışma hayatındaki tutum ve davranışlarını olumsuz etkilemektedir. İş stresi, işe devamsızlık, iş veriminin düşmesi ve işten ayrılma gibi olumsuz sonuçlara neden olabilmektedir (Deveci, 2017:48).

Hastaneler çalışanlar açısından birçok stres faktörünü barındıran çalışma ortamlarıdır (Çögenli ve Erdal, 2018:511). Hastane çalışanları hem mesleki açıdan hem de yönetsel açıdan birçok stres faktörü ile karşı karşıya kalmaktadırlar. Hastane çalışanlarının verimli çalışabilmesi, hastaların iyileştirilmesine odaklanabilmeleri ve hastanelerin sürekliliğinin sağlanabilmesi için iş ortamındaki stres kaynaklarının azaltılması ve çalışanların stres konusunda güçlendirilmesi büyük önem arz etmektedir (Karakuş, 2019:102). Hastane ve sağlık çalışanlarının psikolojik sağlamlık düzeyleri onların yaşadıkları stresin olumsuz sonuçlarından en az şekilde

\section{Psikolojik Sağlamlığın İş Stresine Etkisi: \\ Hastane \\ Çalışanlarına Yönelik Bir Araştırma}


İşletme Bilimi Dergisi (JOBS), 2020; 8(2): 351-370. DOI: 10.22139/jobs.741576

Psikolojik

Sağlamlığın İş

Stresine Etkisi:

Hastane

Çalışanlarına

Yönelik Bir

Araştırma

354 etkilenmelerini sağlamaktadır (McCann et al., 2013:60). Bu çalışma ile hastane çalışanlarının psikolojik sağlamlıkları ve iş stresi düzeylerinin demografik özelliklere göre farklılık gösterip göstermediğinin; ayrıca psikolojik sağlamlık ile iş stresi düzeyleri arasındaki ilişkinin belirlenmesi amaçlanmıştır.

\section{LITERATÜR İNCELEMESI}

\subsection{Psikolojik Să̆lamlık}

Psikolojik sağlamlık, bireylerin karşılaştıkları güçlük veya zorluklar karşısında kendilerini toparlayabilme ve bunların üstesinden gelebilme yeteneğidir (Çetin vd., 2015:82). Başka bir tanıma göre psikolojik sağlamlık, bireylerin önemli değişiklik, zorluk veya riskle karşılaştığında bunlarla başarılı bir şekilde başa çıkabilme yeteneğidir (Stewart et al., 1997:22). Yapılan tanımlar genel tanımlar olup; çalışanlar açısından da psikolojik sağlamlığın tanımı yapılabilir. Buna göre psikolojik sağlamlık, çalışanların örgütte karşılaştıkları ve performanslarını olumsuz etkileyebilecek durum ve koşulların farkında olması ve bunlarla mücadele edebilecek yetenek ve bilgiye sahip olmasıdır (Kanbur et al., 2017:130). Başka bir tanıma göre psikolojik sağlamlık, çalışanların iş stresi ve zorluklar karşısında bireysel ve profesyonel iyilik halini sürdürebilme yeteneğidir (McCann et al., 2013:60$61)$.

Psikolojik sağlamlık, bireylerin zorluklarla baş edebilmesine katkıda bulunan, öğrenilen ve geliştirilebilen bir özelliktir (Buz ve Genç, 2019:623). Bireylerin psikolojik sağlamlık konusunda doğuştan sahip olduğu bazı avantaj ve dezavantajlar olsa da (Ekşi et al., 2019:1698), psikolojik sağlamlık doğuştan sahip olunan bir özellik değildir (Buz ve Genç, 2019:638). Bireylerin yaşadıkları onları psikolojik olarak sağlam hale getirebilirken tam tersi psikolojik olarak zayıf hale de getirebilmektedir. Psikolojik sağlamlık, risk ve koruyucu faktörlerin etkileşiminin sonucunu yansıtmaktadır (Özer ve Deniz, 2014:1241). Risk faktörleri psikolojik sağlamlığı azaltırken, koruyucu faktörler psikolojik sağlamlığı artırmaktadır (Akduman vd., 2018:769). Bu faktörler bireysel, ailevi ve çevresel olmak üzere üç başlıkta ele alınmaktadır. Bu faktörler aşağıda kısaca açıklanmıştır (Öz ve Bahadır Yilmaz, 2009:84):

- Bireysel Faktörler: Bireysel risk faktörleri, geçimsiz mizaca veya utangaç bir kişiliğe sahip olma, ruhsal sorunların olması, alkol veya madde bağımlılığı, akademik başarısızlık gibi faktörlerdir. Bireysel koruyucu faktörler ise, yüksek zeka, bilişsel yetenek, akademik yeterlilik, yüksek benlik sayg1sı, iyimser olmak, hayatı üzerinde kontrol sahibi olmak, 
mizah duygusunun olması, sorumluluk sahibi olmak, problem çözebilme becerisine sahip olmak gibi faktörlerdir.

- Ailevi Faktörler: Ailevi risk faktörleri, ruhsal bozuklukları olan ya da madde bağımlısı olan ebeveynlere sahip olma, ebeveynlerin boşanması, ölümü, ebeveynlerle olumsuz iletişim, ailede şiddete maruz kalmak gibi faktörlerdir. Ailevi koruyucu faktörler ise, olumlu ebeveyn birey ilişkisinin olması, ebeveynlerin bireyi desteklemesi, ebeveynlerin eğitimli olması gibi faktörlerdir.

- Çevresel Faktörler: Çevresel risk faktörleri, sosyo-ekonomik durumun düşüklüğü, yoksulluk, evsizlik, yetersiz beslenme, olumsuz çevre desteği, toplumsal şiddet gibi faktörlerdir. Çevresel koruyucu faktörler ise, sosyo-ekonomik durumun yüksek olması, çevre ile olumlu ilişkilerin olması, toplumsal desteğin olması, olumlu bir rol modelin olması gibi faktörlerdir.

Bireylerin psikolojik olarak sağlam olması çalışma hayatı için de önemli bir avantajdır. Çalışanlar işyerlerinde zamanlarının önemli bir kısmını geçirmektedirler. Bu süre zarfında yönetici baskısı, mobbing, çatışma, kariyer sorunu, adaletsizlik, ücret yetersizliği, zorlu çalışma koşulları gibi birçok olumsuzlukla karşı karşıya kalabilmektedirler. Çalışanların psikolojik sağlamlıklarının yüksek olması karşılaştıkları bu olumsuzlukların üstesinden kolay bir şekilde gelmesini sağlar ve böylece daha verimli ve etkili çalışmasını sağlar (Kavi ve Karakale, 2018:71-73). Ayrıca yapılan araştırmalar incelendiğinde psikolojik sağlamlık çalışanların örgütsel vatandaşlık davranışlarını (Kanbur et al., 2017:133), iş tatminlerini (Polatcı et al., 2017:566) ve örgütsel bağlılıklarını (Polat ve İskender, 2018:5) arttırırken, tükenmişliklerini (Hao et al., 2015:68), iş streslerini ve işten ayrilma niyetlerini (Ghandi et al., 2017:195) azaltmaktadir.

\section{2. İş Stresi}

Stres olgusu, hoş olmayan duygusal bir durumdur (Puteri ve Syaebani, 2018:232). İnsanların esenliği ve huzuru için bir tehlike veya uyarı olarak algılanan durum ya da olaylara karşı gösterilen fizyolojik ve psikolojik tepkiye stres denilmektedir (Akgemici, 2001:302). Başka bir tanıma göre stres, “organizmayı etkileyen herhangi bir şey karşısında organizmanın bedensel ve ruhsal sinırlarının zorlanması ve tehdit edilmesiyle ortaya çıkan bir durumdur" (Yıldırım, 1991:176). Stres bireylerde fizyolojik, zihinsel, duygusal ve davranışsal açıdan birçok soruna neden olabilmektedir. Strese bağlı yaşanabilecek fizyolojik sorunlar arasında; kalp sorunları, çarpıntı, baş dönmesi, baş ağrısı, nefes darlığı, titreme, mide ağrısı, yorgunluk, yüksek tansiyon ve saç dökülmesi gibi
Sağlamlığın İş

Stresine Etkisi:

Hastane

Çalışanlarına

Yönelik Bir

Araştırma 
İşletme Bilimi Dergisi (JOBS), 2020; 8(2): 351-370. DOI: 10.22139/jobs.741576

Psikolojik

Sağlamlığın İş

Stresine Etkisi:

Hastane

Çalışanlarına

Yönelik Bir

Araştırma

356 sorunlar sıralanabilir. Zihinsel ve duygusal sorunlar, endişe, çabuk heyecanlanma, unutkanlık, dikkat dağınıklığı ve hafıza kaybı gibi sorunlardır. Davranışsal sorunlar ise, içe kapanıklık, uykusuzluk, sürekli uyuma isteği, iştahsızlık, yemede artış, konuşma güçlükleri ve madde bağımlılığı gibi sorunlardır (Örücü et al., 2011:6).

Stres bireylerin sadece günlük yaşamlarında değil çalışma ortamlarında da yaşayabilecekleri bir durumdur. Bireylerin çalışma ortamında işle ilgili yaşadıkları stres, iş stresidir. İş stresi, çalışanların çalışma ortamında karşılaştıkları tehdit unsurlarına karşı göstermiş olduğu tepkidir (Chuang ve Lei, 2011:551). Başka bir tanıma göre iş stresi, çalışanların fiziksel ve duygusal açıdan tehdit unsuru olarak algıladığı çalışma ortamındaki durum ya da olaylara karşı göstermiş olduğu tepkidir (Jamal, 2005:130). Stres kişiden kişiye farklılık gösteren öznel bir durumdur. Başka bir ifade ile aynı stres faktörlerine maruz kalan bireylerin verdikleri tepkiler farklılık gösterebilmektedir. Bu durum çalışma hayatı için de geçerli olup; aynı stres faktörleri bazı çalışanların iş stresi yaşamasına neden olurken bazı çalışanları hiçbir şekilde etkilememektedir (Akgemici, 2001:302).

İş stresi çalışanların, işe geç gitme, işe devamsızlık, düşük iş verimliliği, işten ayrılma gibi olumsuz tutum ve davranışlarda bulunmasına neden olabilmektedir (Bayarçelik et al., 2019:494). Ayrıca iş stresi çalışanların iş tatminsizliği, sağlık problemleri, uykusuzluk, yorgunluk, çaresizlik yaşamasına, madde bağımlısı olmasına, çalışma arkadaşlarıyla ve yöneticileriyle sorunlar yaşamasına ve çalıştığı kuruma karşı olumsuz tutum ve davranışlar sergilemesine de neden olabilmektedir (Tel et al., 2003:14; Mojoyinola, 2008:143).

Çalışanların iş stresi yaşamasında birçok faktör etkili olabilmektedir. $\mathrm{Bu}$ faktör bireysel, örgüt ve işle ilgili ve çevresel faktörler olmak üzere üç başlıkta ele alınmaktadır. Bireysel faktörler, çalışanların kişilik ve sosyodemografik özellikleri (yaş, cinsiyet, eğitim durumu gibi) gibi faktörlerdir (Örücü et al., 2011:2). Örgüt ve işle ilgili faktörler, işin tehlikeli ve riskli olması, kötü çalışma koşulları, aşırı iş yükü, vardiyalı çalışma, uzun çalışma saatleri, rol belirsizliği, rol çatışması, mesai arkadaşlarıyla iletişimin zayıf olması, ücretlerin yetersiz olması, kariyer imkanlarının yetersiz olması, katı hiyerarşik örgüt yapısının olması, yönetsel kararlara katılım düzeyinin düşük olması, eğitim eksikliği, ekip çalışmasının yeterli olmaması gibi faktörlerdir (Mojoyinola, 2008:143; Uludağ, 2019:415; Ülker, 2016:29). Çevresel faktörler ise, ülke ekonomisinde yaşanan sorunlar, gelir adaletsizliği, içinde bulunulan çevreye ilişkin olumsuzluklar, yaşanılan şehre ilişkin olumsuzluklar gibi faktörlerdir (Örücü et al., 2011:2). 
Sağlık sektöründe sunulan hizmetin niteliği göz önüne alındığında iş stresine neden olabilecek birçok faktör bulunmaktadır. Hastaneler açısından ele alındığında, sağlık hizmetlerinin sonuçlarının belirsizlikler içermesi, hastaların ihtiyaçlarına hızlı cevap verme gereği, hasta ve yakınlarının taleplerinin değişkenlik göstermesi, yapılacak tıbbi hataların geri dönüşünün zor olması, hasta sirkülasyonun yüksek olması, yetersiz ekipmanla çalışılması, çalışma saatlerinin uzun olması, iş yükünün fazla olması, uyku düzeninin bozulması gibi birçok faktör hastane çalışanlarının iş stresi yaşamasına neden olabilmektedir (Chou et al., 2014:1; Erdilek Karabay, 2015:128).

\section{YÖNTEM}

Araştırma Ocak 2020 - Mayıs 2020 aylarında İstanbul'da gerçekleştirilmiş olup; araştırma verileri anket yöntemi ile toplanmıştır. Araştırmada Dünya Tıp Birliği Helsinki Bildirgesi (2013) etik kurallarına uyulmuştur.

\subsection{Evren ve Örneklem}

Araştırma verileri İstanbul'da faaliyet gösteren özel hastanelerde çalışan bireylerden toplanmıştır. Araştırma evrenini temsil edebilecek örneklem büyüklüğü \%95 güven aralığında 384 kişi olarak belirlenmiştir. Araştırma kapsamında geçerli 391 anket formu toplanmıştır.

\subsection{Veri Toplama Aracı}

Araştırma verilerini toplamak için kullanılan anket formu üç bölümden oluşmaktadır. Anket formunun birinci bölümünde katılımcıların demografik özelliklerinin belirlenmesine ilişkin sorular yer almaktadır. İkinci bölümünde katılımcıların psikolojik sağlamlık düzeyinin belirlenmesine ilişkin ifadeler yer almakta olup; bu bölümde Smith et al. (2008) tarafından geliştirilmiş olan "Kısa Psikolojik Sağlamlık Ölçeği" kullanılmıştır. Ölçek tek boyuttan ve 6 maddeden oluşmaktadır. Ölçeğin Türkçe geçerlilik ve güvenirlik çalışması Doğan (2015) tarafından yapılmıştır. Üçüncü bölümünde ise, katılımcıların iş stresi düzeyinin belirlenmesine ilişkin ifadeler yer almakta olup; bu bölümde Ergün ve Çelik (2015) tarafından House ve Rizzo'nun (1972) çalışmasından Türkçe'ye uyarlanan "İş Stresi Ölçeği" kullanılmıştır. Ölçek tek boyuttan ve 7 maddeden oluşmaktadır. Ölçeğin Türkçe formu için Ergün ve Yüksel'in (2019) çalışmasından yararlanılmıştır. Ölçeklerdeki ifadeler, 5'li Likert tipi ölçek seçenekleri ile ölçülmüştür (1= Kesinlikle Katılmıyorum, 5= Kesinlikle Katılıyorum). Ölçeklerin güvenirlik düzeylerini belirlemek için hesaplanan Cronbach's Alpha katsayılarına göre hem psikolojik sağlamlık ölçeğinin

\section{Psikolojik Sağlamlığın İş Stresine Etkisi: \\ Hastane \\ Çalışanlarına Yönelik Bir Araştırma}


İşletme Bilimi Dergisi (JOBS), 2020; 8(2): 351-370. DOI: 10.22139/jobs.741576

Psikolojik

Sağlamlığın İş

Stresine Etkisi:

Hastane

Çalışanlarına

Yönelik Bir

Araştırma

358 $(\alpha=0,77)$ hem de iş stresi ölçeğinin $(\alpha=0,86)$ güvenirlik düzeylerinin yüksek olduğu belirlenmiştir.

\subsection{Verilerin Analizi}

Verilerin analizinde SPSS 22.0 istatistik paket programı kullanılmıştır. Katılımcıların psikolojik sağlamlık ve iş stresi düzeylerini belirlemek için tanımlayıcı istatistikler hesaplanmıştır. Psikolojik sağlamlık ve iş stresi düzeylerini demografik özelliklere göre karşılaştırmak için iki bağımsız grubun karşılaştırılmasında bağımsız örneklemler için t-testi, ikiden fazla bağımsız grubun karşılaştırılmasında ise tek yönlü varyans analizleri (ANOVA) yapılmıştır. Katılımcıların psikolojik sağlamlık ile iş stresi düzeyleri arasındaki ilişkileri belirlemek için de korelasyon ve regresyon analizi yapılmıştır. Analizler sonucunda elde edilen bulgular \%95 güven aralığında ve \%5 anlamlılık düzeyinde değerlendirilmiştir.

\section{BULGULAR}

Araştırma bulgularına aşağıda yer verilmiştir.

Tablo 1.

Demografik Özelliklerin Dağılımı (n=391)

\begin{tabular}{llcc}
\hline Demografik Özellikler & & $\mathbf{n}$ & $\mathbf{\%}$ \\
\hline \multirow{2}{*}{ Cinsiyet } & Erkek & 122 & 31,2 \\
& Kadın & 269 & 68,8 \\
\multirow{2}{*}{ Yaş } & $\leq 25$ & 169 & 43,2 \\
& $26-35$ & 132 & 33,8 \\
& $\geq 36$ & 90 & 23,0 \\
Eğitim Durumu & Lise & 92 & 23,5 \\
& Önlisans & 121 & 30,9 \\
Hastanedeki Çalışma & Lisans & 133 & 34,0 \\
Süresi & Lisansüstü & 45 & 11,5 \\
\multirow{2}{*}{ Hastanedeki Görev } & $\leq 5$ Y1l & 295 & 75,4 \\
& $\geq 6$ Yıl & 96 & 24,6 \\
& Sağllk Personeli & 138 & 35,3 \\
& Diğer Personel & 253 & 64,7 \\
\hline
\end{tabular}

Tablo 1'e göre katılımcılardan 122 kişi $(\% 31,2)$ erkek, 269 kişi de $(\% 68,8)$ kadındır. Katılımcılardan 169 kişinin $(\% 43,2) 25$ veya altı yaş aralığında, 132 kişinin (\%33,8) 26-35 yaş aralığında, 90 kişinin de (\%23) 36 veya üzeri yaş aralığında dağıldığı belirlenmiştir. Katılımcılardan 92 kişinin $(\% 23,5)$ lise, 121 kişinin (\%30,9) ön lisans, 133 kişinin (\%34) lisans, 45 kişinin de $(\% 11,5)$ lisansüstü eğitime sahip olduğu belirlenmiştir. Katılımcılarından 
295 kişi $(\% 75,4) 5$ yıl veya daha az süredir, 96 kişi de $(\% 24,6) 6$ yıl veya daha fazla süredir halen çalıştıkları hastanelerde çalışmaktadırlar. Katılımcılardan 138 kişi $(\% 35,3)$ sağlık personeli (hekim, ebe, hemşire, laborant gibi), 253 kişi de $(\% 64,7)$ diğer personeldir (idari personel, hasta kabul, elektrik teknisyeni, güvenlik, şoför gibi).

Tablo 2.

Değişkenlere İlişkin Tanımlayıcı İstatistikler

\begin{tabular}{lccccc}
\hline Değişkenler & $\mathbf{n}$ & Ort. & $\begin{array}{c}\text { Std. } \\
\text { Sapma }\end{array}$ & $\begin{array}{c}\text { Çarpıklık } \\
\text { Katsayısı }\end{array}$ & $\begin{array}{c}\text { Basıklık } \\
\text { Katsayısı }\end{array}$ \\
\hline Psikolojik Sağlamlık & 391 & 3,40 & 0,65 & 0,06 & $-0,18$ \\
İş Stresi & 391 & 2,61 & 0,82 & 0,42 & 0,15 \\
\hline
\end{tabular}

Katılımcıların psikolojik sağlamlık $(3,40 \pm 0,65)$ ve iş stresi düzeylerinin $(2,61 \pm 0,82)$ orta düzeyde olduğu belirlenmiştir (Tablo 2).

Tablo 3.

Psikolojik Sağlamlık ve İş Stresi Düzeylerinin Demografik Özelliklere Göre Karşılaştırılması

\begin{tabular}{|c|c|c|c|c|c|c|c|c|}
\hline \multirow{2}{*}{\multicolumn{2}{|c|}{ Demografik Özellikler }} & \multirow[b]{2}{*}{$\mathbf{n}$} & \multicolumn{3}{|c|}{ Psikolojik Sağlamlık } & \multicolumn{3}{|c|}{ İş Stresi } \\
\hline & & & Ort & Std. & & Ort & Std. & \\
\hline \multirow{2}{*}{ Cinsiyet } & Erkek & 122 & 3,65 & 0,67 & $t=5,39$ & 2,48 & 0,85 & $t=-2,14$ \\
\hline & Kadın & 269 & 3,28 & 0,61 & $p=0,00$ & 2,67 & 0,80 & $p=0,03$ \\
\hline \multirow{4}{*}{ Yaş } & $\leq 25$ & 169 & 3,33 & 0,65 & \multirow{4}{*}{$\begin{array}{l}F=1,79 \\
p=0,17\end{array}$} & 2,70 & 0,83 & \multirow{4}{*}{$\begin{array}{l}F=2,76 \\
p=0,06\end{array}$} \\
\hline & $26-35$ & 132 & 3,44 & 0,67 & & 2,59 & 0,79 & \\
\hline & $\geq 36$ & 90 & 3,46 & 0,63 & & 2,46 & 0,83 & \\
\hline & Lise & 92 & 3,39 & 0,71 & & 2,56 & 0,86 & \\
\hline \multirow{3}{*}{$\begin{array}{l}\text { Eğitim } \\
\text { Durumu }\end{array}$} & Ön lisans & 121 & 3,31 & 0,64 & \multirow{3}{*}{$\begin{array}{l}F=2,08 \\
p=0,10\end{array}$} & 2,74 & 0,86 & \multirow{3}{*}{$\begin{array}{l}F=1,85 \\
p=0,14\end{array}$} \\
\hline & Lisans & 133 & 3,42 & 0,61 & & 2,58 & 0,76 & \\
\hline & Lisansüstü & 45 & 3,59 & 0,68 & & 2,43 & 0,78 & \\
\hline \multirow{2}{*}{$\begin{array}{l}\text { Hastanedeki } \\
\text { Çalışma } \\
\text { Süresi }\end{array}$} & $\leq 5$ Yil & 295 & 3,36 & 0,66 & \multirow{2}{*}{$\begin{array}{l}t=-1,80 \\
p=0,07\end{array}$} & 2,63 & 0,84 & \multirow{2}{*}{$\begin{array}{l}t=0,91 \\
p=0,37\end{array}$} \\
\hline & $\geq 6$ Yil & 96 & 3,50 & 0,61 & & 2,54 & 0,75 & \\
\hline \multirow{2}{*}{$\begin{array}{l}\text { Hastanedeki } \\
\text { Görev }\end{array}$} & $\begin{array}{l}\text { Sağlik } \\
\text { Personeli }\end{array}$ & 138 & 3,25 & 0,68 & \multirow{2}{*}{$\begin{array}{l}t=-3,25 \\
p=\mathbf{0 , 0 0}\end{array}$} & 2,82 & 0,87 & \multirow{2}{*}{$\begin{array}{l}t=3,90 \\
p=0,00\end{array}$} \\
\hline & $\begin{array}{l}\text { Diğer } \\
\text { Personel }\end{array}$ & 253 & 3,48 & 0,62 & & 2,49 & 0,77 & \\
\hline
\end{tabular}

Tablo 3'e göre katılımcıların yaşına, eğitim durumuna ve hastanedeki çalışma süresine göre psikolojik sağlamlık ve iş stresi düzeylerinin istatistiksel olarak farklılık göstermediği $(p>0,05)$; ancak katılımcıların
Sağlamliğ

Stresine Etkisi:

Hastane

Çalışanlarına

Yönelik Bir

Araştırma 
İşletme Bilimi Dergisi (JOBS), 2020; 8(2): 351-370. DOI: 10.22139/jobs.741576

Psikolojik

Sağlamlığın İş

Stresine Etkisi:

Hastane

Çalışanlarına

Yönelik Bir

Araştırma

360 cinsiyetine ve hastanedeki görevine psikolojik sağlamlık ve iş stresi düzeylerinin istatistiksel olarak farklılık gösterdiği belirlenmiştir $(p<0,05)$. Farklılıklar incelendiğinde erkek katılımcıların psikolojik sağlamlık düzeylerinin kadın katılımcılara göre daha yüksek olduğu, iş stresi düzeylerinin ise daha düşük olduğu belirlenmiştir. Ayrıca diğer personelin psikolojik sağlamlık düzeylerinin sağlık personeline göre daha yüksek olduğu, iş stresi düzeylerinin ise daha düşük olduğu belirlenmiştir.

Tablo 4.

Psikolojik Sağlamlıkla İş Stresi İlişkisine Dair Korelasyon Analizi

\begin{tabular}{llc}
\hline & & İş Stresi \\
\hline \multirow{3}{*}{ Psikolojik Sağlamlık } & $\mathbf{r}$ & $-0,39$ \\
& $\mathbf{p}$ & 0,00 \\
& $\mathbf{n}$ & 391 \\
\hline
\end{tabular}

Tablo 4'e göre psikolojik sağlamlık ile iş stresi arasında istatistiksel olarak anlamlı bir ilişki vardır $(\mathrm{p}<0,05)$. Korelasyon katsayısına göre $(r=-$ 0,39 ), psikolojik sağlamlık ile iş stresi arasında negatif yönlü ve orta düzeyde bir ilişki vardır.

Tablo 5.

Psikolojik Sağlamlığın İş Stresine Etkisi

\begin{tabular}{llll}
\hline Bağımsız Değişken & $\boldsymbol{\beta}$ & $\mathbf{t}$ & $\mathbf{p}$ \\
\hline Sabit & 4,29 & 21,14 & 0,00 \\
Psikolojik Sağlamlık & $-0,50$ & $-8,45$ & 0,00 \\
\hline & $\mathrm{R}^{2}=0,155$ & $\mathrm{~F}=71,36$ & $\mathrm{p}=0,00$ \\
\hline
\end{tabular}

Bă̆ımlı Değişken: İ̧̧ Stresi

Tablo 5'de yer alan regresyon analizi sonuçlarına göre, psikolojik sağlamlığın iş stresini negatif yönde etkilediği belirlenmiştir $(\beta=-0,50$, $\mathrm{p}<0,05)$. İş stresindeki değişimin \%15,5'inin psikolojik sağlamlık tarafından açıklandığı belirlenmiştir $\left(R^{2}=0,155\right)$. Bu sonuçlar psikolojik sağlamlığın, iş stresinin bir belirleyicisi olduğunu göstermektedir.

\section{TARTIŞMA VE SONUÇ}

Araştırma sonucunda katılımcıların psikolojik sağlamlık düzeylerinin orta düzeyde olduğu belirlenmiştir. Al-Omar et al. (2019:1047) tarafından yapılan araştırmanın sonuçları bu bulguyu desteklerken, ülkemizde yapılmış benzer araştırmalarda ise özel hastane çalışanlarının psikolojik sağlamlık düzeyinin yüksek olduğu belirlenmiştir (Cevizci ve 
Müezzin, 2019:169; Uğan et al., 2018:1471). Yine araştırma sonucunda katılımcıların iş stresi düzeylerinin orta düzeyde olduğu belirlenmiştir. Literatürde yer alan benzer araştırmaların sonuçları da bu bulguyu desteklemektedir (Atan ve Tekingündüz, 2014:58; Ersar1 v et al., 2017:244; Gül, 2007:327; Tekingündüz et al., 2015:33).

Psikolojik sağlamlığın ve iş stresinin orta düzeyde çıkması hastaneler için çok istenilen bir durum değildir. Hem psikolojik sağlamlık hem de iş stresi hastane çalışanlarının çalışma hayatındaki birçok tutum ve davranışını (işe devamlılık, örgütsel bağlılık, örgütsel vatandaşlık davranışı, işten ayrılma niyeti gibi), verimliliğini, performansını ve bağlı olarak hastanelerin verimliliğini ve performansını; ayrıca sunulan sağlık hizmetlerinin kalitesini, hasta memnuniyetini doğrudan ya da dolaylı olarak etkilemektedir. Bu sonuç hastane çalışanlarının psikolojik sağlamlıklarının arttırılması, iş streslerinin de azaltılması gerektiğini göstermektedir.

$\mathrm{Bu}$ araştırmanın amaçlarından biri hastane çalışanlarının psikolojik sağlamlıkları ve iş stresi düzeylerinin demografik özelliklere göre farklılık gösterip göstermediğinin belirlenmesidir. Bu kapsamda elde edilen bulgular incelendiğinde katılımcıların cinsiyetine göre psikolojik sağlamlık düzeylerinin istatistiksel olarak farklılık gösterdiği belirlenmiştir. Literatürdeki benzer araştırmaların sonuçları da bu bulguyu desteklemektedir (Aslan ve Uyar, 2018:16; Ren et al., 2018:60). Araştırma bulguları incelendiğinde erkek katılımcıların psikolojik sağlamlık düzeylerinin kadın katılımcılara göre daha yüksek olduğu belirlenmiştir. Katılımcıların iş stresi düzeylerinin de katılımcıların cinsiyetine göre istatistiksel olarak farklılık gösterdiği belirlenmiştir. Literatürdeki benzer araştırmaların sonuçları incelendiğinde Erşan et al. (2013:117) tarafından yapılan araştırmanın sonuçları bu bulguyu desteklerken, Atan ve Tekingündüz (2014:59) tarafından yapılan araştırmanın sonuçları bu bulguyu desteklememektedir. Araştırma bulguları incelendiğinde kadın katılımcıların iş stresi düzeylerinin erkek katılımcılara göre daha yüksek olduğu belirlenmiştir.

Katılımcıların yaşına göre psikolojik sağlamlık düzeylerinin istatistiksel olarak farkl1lık göstermediği belirlenmiştir. Literatürdeki benzer araştırmaların sonuçları da bu bulguyu desteklemektedir (Aslan ve Uyar, 2018:16; Erdogan et al., 2018:8; Ren et al., 2018:60). Araştırma bulguları incelendiğinde katılımcıların yaşı ilerledikçe psikolojik sağlamlık düzeylerinin arttığı belirlenmiştir. Katılımcıların iş stresi düzeylerinin de katılımcıların yaşına göre istatistiksel olarak farklılık göstermediği belirlenmiştir. Literatürdeki benzer araştırmaların sonuçları da bu bulguyu desteklemektedir (Atan ve Tekingündüz, 2014:59; Erşan et al., 2013:117).
Psikolojik Sağlamlığın İş Stresine Etkisi:

Hastane

Çalışanlarına Yönelik Bir Araştırma 
İşletme Bilimi Dergisi (JOBS), 2020; 8(2): 351-370. DOI: 10.22139/jobs.741576

Psikolojik

Sağlamlığın İş

Stresine Etkisi:

Hastane

Çalışanlarına

Yönelik Bir

Araştırma

362
Araştırma bulguları incelendiğinde katılımcıların yaşı ilerledikçe iş streslerinin azaldığı belirlenmiştir.

Katılımcların eğitim durumuna göre psikolojik sağlamlık düzeylerinin istatistiksel olarak farklılık göstermediği belirlenmiştir. Ancak literatürdeki benzer araştırmaların sonuçları bu bulguyu desteklememektedir (Aslan ve Uyar, 2018:17; Erdogan et al., 2018:8; Ren et al., 2018:60). Araştırma bulguları incelendiğinde eğitim durumu lisans ve lisansüstü olan katılımcıların psikolojik sağlamlık düzeylerinin daha yüksek olduğu belirlenmiştir. Katılımcıların iş stresi düzeylerinin de katılımcıların eğitim durumuna göre istatistiksel olarak farklılık göstermediği belirlenmiştir. Literatürdeki benzer araştırmaların sonuçları bu bulguyu desteklememektedir (Atan ve Tekingündüz, 2014:59; Erşan et al., 2013:117). Araştırma bulguları incelendiğinde ön lisans eğitime sahip katılımcıların iş streslerinin diğer eğitim durumuna sahip katılımcılara göre daha yüksek olduğu belirlenmiştir.

Katılımcların görev yaptıkları hastanelerdeki çalışma süresine göre psikolojik sağlamlık düzeylerinin istatistiksel olarak farklılık göstermediği belirlenmiştir. Erdogan et al. (2018:9) tarafından hemşirelere yönelik yapılmış olan araştırmanın sonuçları da bu bulguyu desteklemektedir. Araştırma bulguları incelendiğinde görev yaptıkları hastanelerde 6 yıl veya daha fazla süredir çalışan katılımcıların psikolojik sağlamlık düzeylerinin daha yüksek olduğu belirlenmiştir. Katılımcıların iş stresi düzeylerinin katılımcıların görev yaptıkları hastanelerdeki çalışma süresine göre istatistiksel olarak farklılık göstermediği belirlenmiştir. Araştırma bulguları incelendiğinde görev yaptıkları hastanelerde 6 yıl veya daha fazla süredir çalışan katılımcıların iş stresi düzeylerinin daha düşük olduğu belirlenmiştir.

Katılımcıların çalıştıkları hastanelerdeki görevine göre psikolojik sağlamlık düzeylerinin istatistiksel olarak farklılık gösterdiği belirlenmiştir. Araştırma bulguları incelendiğinde diğer personelin psikolojik sağlamlık düzeylerinin sağlık personeline göre daha yüksek olduğu belirlenmiştir. Aslan ve Uyar'ın (2018:18) yapmış oldukları benzer araştırmanın sonuçlarına göre hastanedeki görevine göre katılımcıların psikolojik sağlamlık düzeylerinin istatistiksel olarak farklılık göstermediği belirlenmiştir. Araştırma bulgularına göre katılımcıların iş stresi düzeylerinin de katılımcıların çalıştıkları hastanelerdeki görevine göre istatistiksel olarak farklılık gösterdiği belirlenmiştir. Literatürdeki benzer araştırmaların sonuçları da bu bulguyu desteklemektedir (Atan ve Tekingündüz, 2014:59; Erşan et al., 2013:117). Araştırma bulguları 
incelendiğinde sağlık personelinin iş stresinin diğer personele göre daha yüksek olduğu belirlenmiştir.

$\mathrm{Bu}$ araştırmanın amaçlarından bir diğeri de katılımcıların psikolojik sağlamlık ile iş stresi düzeyleri arasındaki ilişkinin belirlenmesidir. Bu kapsamda elde edilen bulgular incelendiğinde psikolojik sağlamlık ile iş stresi arasında istatistiksel olarak anlamlı, negatif yönlü ve orta düzeyde bir ilişkinin olduğu belirlenmiştir. Ayrıca psikolojik sağlamlığın iş stresini negatif yönde etkilediği belirlenmiştir. Literatürdeki farklı sektörlerde yapılmış araştırmaların sonuçları da bu bulguları desteklemektedir (Jahromi ve Chinaveh, 2018:280; Hao et al., 2015:67-68).

Araştırma sonuçları çerçevesinde çalışanların psikolojik sağlamlıklarının arttırılması ve iş streslerinin azaltılması için hastane yönetimlerinin bazı çalışmalar yapması önerilmektedir. Bu kapsamda çalışanların belli aralıklarla psikolojik sağlamlık ve iş stresi düzeylerinin ölçülmesi ve gerekli durumda psikolojik destek verilmesi, çalışanlara örgütsel desteğin verilmesi, yöneticilerin çalışanların kurumda yaşadığ sorunlara çözüm bulması, çalışanlara eğitimler verilmesi, çalışma koşullarının iyileştirilmesi, ekip ruhunun geliştirilmesi, çalışanların stresini azaltacak çeşitli organizasyonların ve aktivitelerin yapılması önerilmektedir. $\mathrm{Bu}$ araştırmanın yüksek olmayan sayıda katılımcıyla yapılmış olması bir sınırlılık olsa da, psikolojik sağlamlığın iş stresine etkisinin özel hastaneler özelinde ortaya konulması bakımından önemlidir. Konuyla ilgili benzer araştırmaların daha fazla katılımcıyla yapılmasının faydalı olacağ düşünülmektedir.

\section{KAYNAKÇA}

Akduman, G., Karahan, G. ve Solmaz, M.S. (2018). İletişim Becerileri Üstünde Empati ve Psikolojik Sağlamlığın Etkisi: Sivil Havacılık Kabin Hizmetleri ve Deniz Ulaştırma İşletme Mühendisliği Öğrencileriyle Karşılaştırmalı Bir Araştırma. Finans Ekonomi ve Sosyal Araştırmalar Dergisi (FESA), 3(4): 765-775. Doi: $10.29106 /$ fesa.494713

Akgemci, T. (2001). Örgütlerde Stres ve Yönetimi. Atatürk Üniversitesi İktisadi ve İdari Bilimler Dergisi, 15(1-2): 301-309.

Al-Omar, H.A., Arafah, A.M., Barakat, J.M., Almutairi, R.D., Khurshid, F. ve Alsultan, M.S. (2019). The Impact of Perceived Organizational Support and Resilience on Pharmacists' Engagement in their Stressful and Competitive Workplaces in Saudi Arabia. Saudi Pharmaceutical Journal, 27(7): 1044-1052. Doi: 10.1016/j.jsps.2019.08.007
Sağlamlığın İş

Stresine Etkisi:

Hastane

Çalışanlarına

Yönelik Bir

Araştırma 
İşletme Bilimi Dergisi (JOBS), 2020; 8(2): 351-370. DOI: 10.22139/jobs.741576

Psikolojik

Sağlamlığın İş

Stresine Etkisi:

Hastane

Çalışanlarına

Yönelik Bir

Araştırma

364

Aslan, Ş. ve Uyar, S. (2018). Sağlık Çalışanlarında Mükemmeliyetçilik, Özgüven, Kendini Sabotaj ve Psikolojik Dayanıklı̆̆ının Sosyo Demografik Açıdan Farklılıkları. Selçuk Üniversitesi Akşehir Meslek Yüksekokulu Sosyal Bilimler Dergisi, 2(9): 11-24.

Atan, M. ve Tekingündüz, S. (2014). Ambulans Çalışanlarının (112) Tükenmişlik, Algılanan İşs Stresi ve İş Tatminlerinin Kişisel Özelliklere Göre İncelenmesi. NWSA-Social Sciences, 9(3): 54-69. Doi: 10.12739/NWSA.2014.9.3.3C0121

Bayarçelik, E.B., Durmaz, B.V. ve Gürler, E.N. (2019). İş Stresi ve Pozitif Psikolojik Sermayenin Tükenmişlik Üzerine Etkisi: Bankacilık Sektöründe Bir Araştırma. İnsan $\mathcal{E} \quad$ Insan, 6(21): 493-523. DOI: Doi: 10.29224/insanveinsan.513475

Buz, S. ve Genç, B. (2019). Sosyal Hizmet Uzmanları İçin Psikolojik Dayanıklılı̆̆ın Önemi. Toplum ve Sosyal Hizmet, 30(2): 623-642.

Cevizci, O. ve Müezzin, E.E. (2019). Sağllk Çalışanlarında Psikolojik Belirtilerin ve Psikolojik Dayanıklılı̆ı̆n İncelenmesi. Kıbrıs Türk Psikiyatri ve Psikoloji Dergisi, 1(3): 166-172. Doi:10.35365/ctjpp.19.1.21

Chou, L.P., Li, C.Y. ve Hu, S.C. (2014). Job Stress and Burnout in Hospital Employees: Comparisons of Different Medical Professions in a Regional Hospital in Taiwan. BMJ Open, 4(2): 1-7. Doi:10.1136/bmjopen-2013-004185

Chuang, N.K. ve Lei, S.A. (2011). Job Stress Among Casino Hotel Chefs in a Top-Tier Tourism City. Journal of Hospitality Marketing \& Management, 20(5): 551-574. Doi: 10.1080/19368623.2011.570642

Cooke, F.L., Wang, J. ve Bartram, T. (2019). Can a Supportive Workplace Impact Employee Resilience in a High Pressure Performance Environment? An Investigation of the Chinese Banking Industry. Applied Psychology: An International Review, 68(4): 695-718. Doi: 10.1111/apps.12184

Çetin, F., Yeloğlu, H.O. ve Basım, H.N. (2015). Psikolojik Dayanıklılı̆̆ın Açılanmasında Beş Faktör Kişilik Özelliklerinin Rolü: Bir Kanonik İlişki Analizi. Türk Psikoloji Dergisi, 30(75): 81-92.

Çınar, O. (2010). Eğitim ve Sağlık Alanı Çalışanlarının İş Stresi Düzeyleri. Elektronik Sosyal Bilimler Dergisi, 9(33): 101-121.

Çögenli, M.Z. ve Erdal, Y. (2018). Hemşirelerde İş Stresi ve İş Stresinin Çalışma Performansına Etkileri: Sinop Atatürk Devlet Hastanesi Örneği. Business $\mathcal{E}$ Management Studies: An International Journal, 6(3): 497-515. Doi: 10.15295/bmij.v6i3.361

Deveci, B. (2019). İş Stresi ve Turizm İşletmelerinde Yapılan Araştırmalara İlişkin Bir Değerlendirme. Mehmet Akif Ersoy Üniversitesi Sosyal Bilimler Enstitüsü Dergisi, 9(20): 39-53. Do1: 10.20875/makusobed.306671 
Doğan, T. (2015). Kısa Psikolojik Sağlamlık Ölçeği'nin Türkçe Uyarlaması: Geçerlik ve Güvenirlik Çalışması. The Journal of Happiness \& Well-Being, 3(1): 93-102.

Ekşi, H., Boyalı, C. ve Ümmet, D. (2019). Öğretmen Adaylarının Spiritüel İyi Oluş İle Yaşamda Anlam Değişkenlerinin Psikolojik Dayanıklılığı Yordaması: Bir Yapısal Eşitlik Modeli (YEM) Denemesi. Kastamonu Eğitim Dergisi, 27(4): 16951704. Dor: 10.24106/kefdergi.3256

Erdilek Karabay, M. (2015). Sağlık Personelinin İş Stresi, İş- Aile Çatışması ve İşAile-Hayat Tatminlerine Yönelik Algılarının İşten Ayrılma Niyeti Üzerindeki Etkilerinin Belirlenmesi Üzerine Bir Araştırma. Yönetim Bilimleri Dergisi, Cilt: 13, Sayı: 26: 113-134.

Erdogan, T.K., Sener, A., Masat, S., Kaya, G., Palazoglu, C.A. ve Koc, Z. (2018). The Factors affecting the Resilience Levels of the Nurses Working in a Public Hospital. New Trends and Issues Proceedings on Advances in Pure and Applied Sciences, 10: 1-11.

Ergün, E. ve Çelik, S. (2015). Yöneticilerin Görev ve Çalışan Odaklı Liderlik Davranışları ve Hemşirelerin İş Tatmini, Örgütsel Bağlılı̆̆ı ve İş Stresi Arasındaki İlişki. Florence Nightingale Hemşirelik Dergisi, 23(3): 203-214.

Ergün, E. ve Yüksel, A. (2019). İş-Yaşam Çatışmasının Çalışanın Davranışsal Sonuçlarına Etkisi ve İş Stresinin Aracılık Rolü. İstanbul Aydın Üniversitesi Dergisi (İÄ̈D), 11(1): 67-90. Doi: 10.17932/IAU.IAUD.m.13091352.2019.1/41.67-90

Ersarı, G., Turan Torun, B. ve Naktiyok, A. (2017). Duygusal Emeğin İş Stresi Üzerine Etkisinde Öz Yeterliliğin Aracllık Rolü: Hemşireler Üzerine Bir Uygulama. Van Yüzüncü Yal Üniversitesi Sosyal Bilimler Enstitüsü Dergisi, 38: 229-250.

Erşan, E.E., Yıldırım, G., Doğan, O. ve Doğan, S. (2013). Sağlık Çalışanlarının İş Doyumu ve Algılanan İş Stresi ile Aralarındaki İlişkinin İncelenmesi. Anadolu Psikiyatri Dergisi, 14(2): 115-121. Doi: 10.5455/apd.34482

Ghandi, P., Hejazi, E. ve Ghandi, N. (2017). A Study on the Relationship between Resilience and Turnover Intention: With an Emphasis on the Mediating Roles of Job Satisfaction and Job Stress. Bull. Soc. R. Sci. Liege, 86: 189-200.

Gül, H. (2007). İş Stresi, Örgütsel Sağllk ve Performans Arasındaki İlişkiler: Bir Alan Araştırması. Karamanoğlu Mehmetbey Üniversitesi Sosyal ve Ekonomik Araştırmalar Dergisi, 2: 318-332.

Hao, S., Hong, W., Xu, H., Zhou, L. ve Xie, Z. (2015). Relationship between Resilience, Stress and Burnout among Civil Servants in Beijing, China: Mediating and Moderating Effect Analysis. Personality and Individual Differences, 83: 65-71. Doi:0.1016/j.paid.2015.03.048

\section{Psikolojik Sağlamlığın İş Stresine Etkisi: \\ Hastane \\ Çalışanlarına Yönelik Bir Araştırma}


İşletme Bilimi Dergisi (JOBS), 2020; 8(2): 351-370. DOI: 10.22139/jobs.741576

Psikolojik

Sağlamlığın İş

Stresine Etkisi:

Hastane

Çalışanlarına

Yönelik Bir

Araştırma

366
House, R.J. ve Rizzo, J.R. (1972). Role Conflict and Ambiguity as Critical Variables in a Model of Organizational Behavior. Organizational Behavior and Human Performance, 7(3): 467-505.

Jahromi, F.D. ve Chinaveh, M. (2018). Prediction Job Stress based on Resilience and Coping Strategies in Driving School Instructors. Indian Journal of Positive Psychology, 9(2): 279-281.

Jamal, M. (2005). Short Communication: Personal and Organizational Outcomes related to Job Stress and Type-A Behavior: A Study of Canadian and Chinese Employees. Stress and Health, 21(2): 129-137. Doi: 10.1002/smi.1047

Kanbur, E., Kanbur, A. ve Özdemir, B. (2017). Psikolojik Dayanıklılık ile Örgütsel Vatandaşlık Davranışı Arasındaki İlişkide İş Doyumunun Aracılık Rolü: Havacıllk Sektöründe Bir Araştırma. İş ve İnsan Dergisi, 4(2): 127-141. Doi: 10.18394/iid.321941

Karakuş, Ç. (2019). Çalışma Hayatında İş Tatmini ve İş Stresi: Özel Bir Hastanede Çalışan Hemşireler Üzerine Bir Araştırma. Kırşehir Ahi Evran Üniversitesi İktisadi ve İdari Bilimler Fakültesi Dergisi, 3(1): 92-104.

Kavi, E. ve Karakale, B. (2018). Çalışan Psikolojisi Açısından Psikolojik Dayanıklılık. HAK-IŞ Uluslararası Emek ve Toplum Dergisi, 7(17): 55-77. Doı: 10.31199/hakisderg.391826

McCann, C.M., Beddoe, E., McCormick, K., Huggard, P., Kedge, S., Adamson, C. ve Huggard, J. (2013). Resilience in the Health Professions: A Review of Recent Literature. International Journal of Wellbeing, 3(1): 60-81. Doi:10.5502/ijw.v3i1.4

Mojoyinola, J.K. (2008). Effects of Job Stress on Health, Personal and Work Behaviour of Nurses in Public Hospitals in Ibadan Metropolis, Nigeria. Studies on EthnoMedicine, 2(2): 143-148.

Örücü, E., Kılıç, R. ve Ergül, A. (2011). Çalışma Yaşamında Stresin Bireysel Performans Üzerindeki Etkileri: Eğitim ve Sağlık Çalışanlarına Yönelik Bir Araştırma. Akademik Bakış Dergisi, 26: 1-21.

Öz, F. ve Bahadır Yılmaz, E. (2009). Ruh Sağllğının Korunmasında Önemli Bir Kavram: Psikolojik Sağlamlık. Hacettepe Üniversitesi Sağlık Bilimleri Fakültesi Hemşirelik Dergisi, 16(3): 82-89.

Özer, E. ve Deniz, M.E. (2014). Üniversite Öğrencilerinin Psikolojik Sağlamlık Düzeylerinin Duygusal Zeka Açısından İncelenmesi. İlköğretim Online, 13(4): 1240-1248. Doi: 10.17051/io.2014.74855

Polat, D.D. ve İskender, M. (2018). Exploring Teachers' Resilience in Relation to Job Satisfaction, Burnout, Organizational Commitment and Perception of Organizational Climate. International Journal of Psychology and Educational Studies, 5(3): 1-13. 
Polatcı, S., Irk, E., Gültekin, Z. ve Sobacı, F. (2017). Psikolojik Dayanıklılık ve Kişilik Özellikleri Tatmin Düzeyini Etkiler mi?. Süleyman Demirel Üniversitesi Sosyal Bilimler Enstitüsü Dergisi, 2017/4, 29: 553-578.

Puteri, L.A. ve Syaebani, M.I. (2018). Employees Work Stress Level in the Hospital. International Research Journal of Business Studies, 11(3): 231-243. Doi:10.21632/irjbs

Ren, Y., Zhou, Y., Wang, S., Luo, T., Huang, M. ve Zeng, Y. (2018). Exploratory Study on Resilience and Its Influencing Factors among Hospital Nurses in Guangzhou, China. International Journal of Nursing Sciences, 5(1): 57-62. Doi: 10.1016/j.ijnss.2017.11.001

Smith, B.W., Dalen, J., Wiggins, K., Tooley, E., Christopher, P. ve Bernard, J. (2008). The Brief Resilience Scale: Assessing the Ability to Bounce Back. International Journal of Behavioral Medicine, 15(3): 194-200. Doi: 10.1080/10705500802222972

Stewart, M., Reid, G. ve Mangham, C. (1997). Fostering Children's Resilience. Journal of Pediatric Nursing, 12(1): 21-31.

Tekingündüz, S., Kurtuldu, A. ve Öksüz, S. (2015). İş-Aile Yaşam Çatışması, İş Tatmini ve İş Stresi Arasındaki İlişkiler. Siyaset, Ekonomi ve Yönetim Araştırmaları Dergisi: 3(4): 27-42.

Tel, H., Karadağ, M., Tel, H. ve Aydın, Ş. (2003). Sağlık Çalışanlarının Çalışma Ortamındaki Stres Yaşantıları ile Başetme Durumlarının Belirlenmesi. Hemşirelikte Araştırma Geliştirme Dergisi, 5(2): 13-23.

Türk, K., Eroğlu, C. ve Türk, D. (2008). T.C. Devlet Hastanelerindeki Çalışma Koşullarının Stres Üzerine Etkilerini Ölçmeye Yönelik Bir Araştırma: Geyve Devlet Hastanesi Örneği. Uluslararası İnsan Bilimleri Dergisi, 5(1): 1-17.

Uğan, Ç., Karakaya, F. ve Nayır, Y. (2018). Psikolojik Sermayenin İşgören Performansı ve İş Stresine Etkisi. Ömer Gider, Tuncay Köse ve Tezcan Şahin (Ed.), Uluslararası 12. Ulusal Sağlık ve Hastane İdaresi Kongresi, 1468-1475. Muğla: Muğla Sıtkı Koçman Üniversitesi Yayını.

Uludağ, G. (2019). İşs Stresi ve Motivasyon İlişkisine Yönelik Bir Alan Araştırması. Adryaman Üniversitesi Sosyal Bilimler Enstitüsü Dergisi, 12(33): 411-439. Doi: 10.14520/adyusbd.605567

Ülker, N. (2016). Hastanede Çalışanların Stres ve Yönetimi. Balkan ve Yakındoğu Üniversitesi Sosyal Bilimler Dergisi, 2(2): 28-37.

Yıldırım, İ. (1991). Stres ve Stresle Başaçıkmada Gevşeme Teknikleri. Hacettepe Üniversitesi Ĕ̆itim Fakültesi Dergisi, 6: 175-189.
Sağlamlığın İş

Stresine Etkisi:

Hastane

Çalışanlarına

Yönelik Bir

Araştırma 
Psikolojik

Sağlamlığın İş

Stresine Etkisi:

Hastane

Çalışanlarına

Yönelik Bir

Araştırma

368

\section{THE EFFECT OF RESILIENCE ON THE JOB STRESS: A STUDY ON HOSPITAL EMPLOYEES}

\section{EXTENDED ABSTRACT}

Aim: Individuals might encounter various negative situations throughout their lives. While some individuals can handle the effects of the negative situations in a very short time, some individuals might be exposed to the effects of such negative situations for a long time. The power of individuals to bounce back and return their regular lives quickly is explained by the concept of resilience. (Doğan, 2015:93). Resilience is an important concept for working life as in daily life. Resilience affects various attitudes and behaviors, productivity, performance of the employees in their working life and, correspondingly it also affects the productivity and performance of organizations. Job related stress is another issue which is affected by resilience. Through the effect of globalization and technological developments, current working life and business methods have changed significantly, the competition has increased hence the conditions of the working environment and the individuals way of life have changed. All these factors caused employees to get more stressed due to the job. Hospital employees might experience extreme stress due to job. As the outcomes of health services are not clear, the requirement for quick response to the needs and varying demands of patients and their relatives, the wrong medical applications which are hard to remedy, high patient circulation, insufficient working equipment, long working hours, excessive workload, irregular sleeping pattern and some other factors may cause the hospital employees to experience job stress (Chou et al., 2014: 1; Erdilek Karabay, 2015: 128). Job stress also affects various attitudes and behaviors, productivity, performance of the employees in their working life and, correspondingly it also affects the productivity and performance of organizations. Within the scope of this study, it is considered that the resilience is one of the factors which reduce the job stress of the employees. In this study, it is aimed to determine whether the resilience and job stress levels of hospital employees differ in line with the demographic characteristics; and to determine the relationship between resilience and job stress levels.

Method: This research was performed in Istanbul between January 2020 and May 2020. The data of this research was collected from individuals who work in private hospitals in Istanbul through survey method. The survey form of this research consists of three parts. In the first part of the survey form, there are questions for determining the demographic characteristics of the 
participants. In the second part, there are some questions for determining the resilience level of the participants through the Brief Resilience Scale which was developed by Smith et al. (2008). This is a single dimension scale with 6 items. The validity and reliability of the scale for Turkish language was proved by Doğan (2015). In the third part, there are questions for determining the level of job stress of the participants; in this section, the "Job Stress Scale" was used which is a study of House and Rizzo (1972) as adapted into Turkish by Ergün and Çelik's (2015). This is a single dimension scale with 7 items. The Turkish form of the scale is used which was adopted in the study of Ergün and Yüksel (2019). Questions in the scales were measured with 5 point Likert type scale options $(1=$ Strongly Disagree, $5=$ Strongly Agree). 391 survey forms were filled within the scope of research. SPSS 22.0 statistics software was used for the analysis of the data. The descriptive statistics were calculated in order to determine the resilience and job stress levels of the participants. In order to compare resilience and job stress levels by considering the demographic characteristics; independent samples t-test was used to compare two independent groups, and one-way analysis of variance (one-way ANOVA) analyzes were applied in order to compare more than two independent groups. The correlation and regression analysis were also applied in order to determine the determinant between participants' resilience and job stress levels.

Findings: In the research, it is determined that resilience (3.40 \pm 0.65$)$ and job stress levels $(2.61 \pm 0.82)$ of the participants were at a moderate level. It was found that the resilience and job stress levels of the participants do not differ statistically in terms of their age, education level, and working time in the current hospital ( $p>0.05)$. However, it was found that the resilience and job stress levels of the participants differ statistically in terms of their gender and the task of the hospital $(\mathrm{p}<0.05)$. Depending on the research results, a statistically significant, negative, and moderate relationship was found between resilience and job stress $(r=-0.39, \mathrm{p}<0.05)$. Furthermore, it was found that resilience affects job stress negatively $(\beta=-0.50, p<0.05)$. It was also found that $15.5 \%$ of the change in job stress can be explained by resilience $(\mathrm{R} 2 \mathrm{=} \mathbf{0 . 1 5 5 )}$.

Results: As a result of the research, the resilience and job stress levels of the participants were found at a moderate level. This situation does not satisfy the hospitals. Both resilience and job stress, directly and indirectly, affect the attitudes and behaviors, productivity, the performance of hospital employees in their working life, and also the productivity and performance of hospitals and the quality of services in relation to this situation. Another finding of this research shows that resilience is a determinant of job stress.

\section{Psikolojik Sağlamlığın İş Stresine Etkisi: \\ Hastane \\ Çalışanlarına Yönelik Bir Araştırma}


Psikolojik

Sağlamlığın İş

Stresine Etkisi:

Hastane

Çalışanlarına

Yönelik Bir

Araştırma

370
Within the framework of all these research results, it is recommended that hospital management should perform some studies in order to increase the resilience of employees and reduce job stress. In this context, it is recommended to measure the resilience and job stress levels of the employees with regular intervals and to provide psychological support and organizational support to the employees if required, to find solutions for the problems of the employees in the institution, to provide training for the employees, to improve the working conditions, to develop the team spirit, to arrange various events and activities that would reduce the stress of the employees. Although it is a limitation that the population of the research was not high, it provides significant results that reveal the effect of resilience on job stress in private hospitals. It is suggested that it would be beneficial to perform similar researches with a bigger population.

Keywords: Resilience, Job Stress, Hospital 